\title{
Investigating personal characteristics on e-banking adoption
}

\author{
Ali Arfaeian ${ }^{a}$, Behnam Ghorbanifard ${ }^{b}$, Seyed Shahab Mousavi ${ }^{a^{*}}$ and Hosseinali Aziziha $^{a}$
}

${ }^{a}$ Department of Management, South Tehran Branch, Islamic Azad University, Tehran, Iran ${ }^{b}$ Department of Management, Payame Nour University, Karaj Unit, Karaj, Iran

\section{CH R O N I C L E}

\section{Article history:}

Received August 16, 2013

Received in revised format

12 September 2013

Accepted 1 November 2013

Available online

November 12013

Keywords:

Online banking

Neuroticism

Extraversion

Openness to experience

Conscientiousness

Agreeableness

\begin{abstract}
A B S T R A C T
During the past few years, there have been increasing interests on doing banking transactions using online services through internet. In this paper, we present an empirical investigation to study the role of personal and social characteristics on acceptance of e-banking adoption. The proposed study designs two questionnaires and distributes them among 384 randomly selected people who use online banking in province of Alborz, Iran. The proposed study examines the effects of five factors including Neuroticism, Extraversion, Openness to experience, Conscientiousness and Agreeableness on e-banking adoption. Using regression techniques, the study has confirmed that Neuroticism and Agreeableness have negative and meaningful impact on e-banking adoption while Conscientiousness has positive and meaningful relationship with e-banking adoption.
\end{abstract}

\section{Introduction}

Now a day, online banking is one of the most popular features used by most people around the world and detecting different factors influencing customer perception and behavior towards and satisfaction with e-banking plays essential role on most banks' strategies. These days, most financial institutions offer new banking channels to their own customers, as technology adds new dimensions to the classic banking systems. Internet banking is considered as one of the most popular self-service banking technologies. To obtain this understanding in respect of Indian customers, Agarwal et al. (2009) conducted on respondents chosen from the northern part of India. They reported that customers were influenced in their usage of e-banking services by the type of account they hold, their age and profession, attach highest degree of usefulness to balance enquiry service among e-banking services. Akturan and Tezcan (2012) studied consumers' mobile banking adoption through an integration of the technology acceptance model (TAM) with work on perceived benefits and perceived risks. They

* Corresponding author. Tel: +989355155108

E-mail addresses: surajkushe@gmail.com (S. S. Mousavi)

(C) 2013 Growing Science Ltd. All rights reserved.

doi: $10.5267 / j . m s 1.2013 .11 .003$ 
reported that perceived usefulness, perceived social risk, perceived performance risk and perceived benefit directly influence attitudes towards mobile banking, and attitude was the major determinant of mobile banking adoption intention.

Moon and Kim (2001) presented playfulness as a new measure, which reflects the user's intrinsic belief in WWW acceptance and extended TAM for the WWW context. Venkatesh and Davis (2000) reported another theoretical extension of the TAM for mobile industry. Cruz et al. (2010) studied the perceived barriers to the adoption of mobile banking services among Brazilian internet users and investigated patterns based on socio-demographics variables. They reported that the majority of respondents had not applied any kind of mobile banking service. Perception of cost, risk, low perceived relative advantage and complexity were revealed to be the primary reasons behind the reluctance to apply the service.

Calisir and Gumussoy (2008) investigated how young consumers perceive Internet banking in association with other six banking channels. They used correspondence and cluster analysis and reported that the banking channels that were close with Internet banking. Their results also revealed that Internet banking, ATM, and phone banking substituted each other and Internet banking was considered to be efficient for ease of use and access, and that the users of Internet banking lack confidence in the security of the web sites of Internet banking.

Koenig-Lewis et al. (2010) studied the barriers for enhancing mobile banking services by looking into two widely used models for technology adoption: the Technology Acceptance Model (TAM) and Innovation Diffusion Theory (Dillon \& Morris, 1996; Venkatesh et al., 2003). They studied a model to forecast consumers' intention to apply mobile banking. The results of their survey indicated that compatibility, perceived usefulness, and risk were significant indicators for e-banking adoption. Compatibility not only maintained a strong direct influence but was also detected as an essential antecedent for perceived ease of use, perceived usefulness and credibility. Trust and credibility in their study were crucial in reducing the overall perceived risk of e-banking.

Chau and Ngai (2010) performed an investigation on the perceptions, attitudes and behavior of the youth market for internet banking services (IBS). They reported that young people (age 16-29) maintained positive behavior towards using IBS compared with others did. They also reported a positive effect between IBS quality on satisfaction and loyalty. Suoranta and Mattila (2004) investigated diffusion and adopters of mobile banking services by investigating some contradictory empirical results drawn from a mobile banking survey. They provided an indication of the characteristics of potential subsequent adopters of mobile banking, and of some changes between user segments. Laforet and Li (2005) did a survey on the market status for online/mobile banking in China and reported that Chinese online and mobile bank users were males, not necessarily young and highly educated, in contrast with the electronic bank users in the West. The issue of security was detected to be the most essential factor that motivated Chinese consumer adoption of e-banking. They reported the main barriers to online banking as the perception of risks, computer and technological skills and Chinese traditional cash-carry banking culture.

Riquelme and Rios (2010) investigated the moderating impact of gender on the adoption of mobile banking. They tested the factors impacting adoption of mobile banking among current e-banking users in Singapore and gender as a moderating variable. They reported that usefulness, social norms (King \& He, 2006) and social risk, in this order, were the factors influenced the intention to adopt mobile banking services the most. Lu et al. (2008) studied the factors affecting adoption of wireless mobile data services (WMDS) in China and examined their model for describing adoption intentions there. They argued that individuals form their intention to use WMDS under the impact of wireless mobile technology, the social environment, personal innovativeness of IT, trust awareness, and the facilitating conditions. They examined the simultaneous effects of these five factors on beliefs in the 
context of wireless Internet data services via mobile phones and reported that WMDS adoption intention in China was determined by consumers' perceived usefulness and perceived ease of implementation of WMDS.

Jarvenpaa and Todd (1996) studied consumer reactions to electronic shopping on the World Wide Web. Hu et al. (1999) investigated the technology acceptance model based on physician acceptance of telemedicine technology. Morris and Dillon (1997) detected how user perceptions could possibly impact software use. Littler and Melanthiou (2006) studied consumer perceptions of risk and uncertainty and the implications for behavior towards innovative retail services in a case study of ebanking. Gupta et al. (2008) studied adoption of ICT in a government organization in a developing country. Im et al. (2008) examined the impacts of perceived risk and technology type on users' acceptance of technologies. Kuo and Yen (2009) tried to understand more about the consumer intention to use $3 \mathrm{G}$ mobile value-added services. Yiu et al. (2007) investigated various factors affecting the adoption of e-banking in Hong Kong-implications for the banking sector. Eriksson et al. (2008) studied the adoption of commercial innovations in the former Central and Eastern European markets in a case of internet banking in Estonia.

\section{The proposed model}

In this paper, we present an empirical investigation to study the role of personal and social characteristics on acceptance of e-banking adoption. The proposed study designs two questionnaires and distributes them among some randomly selected people who use online banking in province of Alborz, Iran. The sample size of the study has been calculated as follows, $N=Z_{\alpha / 2}^{2} \frac{p \times q}{e^{2}}$,

where $N$ is the sample size, $p=1-q$ represents the probability, $z_{\alpha / 2}$ is CDF of normal distribution and finally $\varepsilon$ is the error term. For our study we assume $p=0.5, z_{\alpha / 2}=1.96$ and $e=0.05$, the number of sample size is calculated as $N=384$. The proposed study examines the effects of five factors including Neuroticism, Extraversion, Openness to experience, Conscientiousness and Agreeableness on accepting online banking. Fig. 1 shows details of our survey,

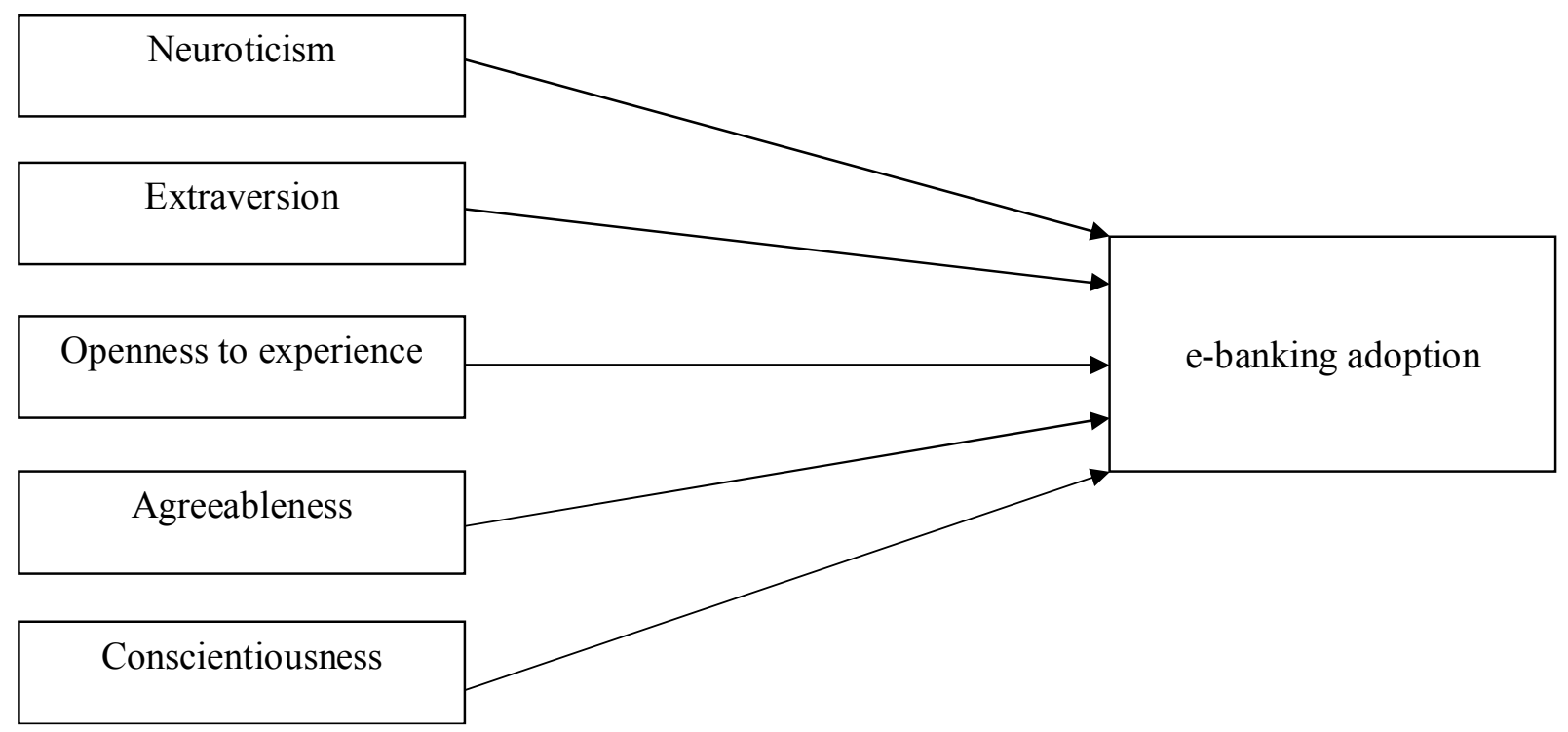

Fig. 1. The proposed study

Based on the Fig. 1, the following five hypotheses are investigated in this study. 
1. There is a negative and meaningful relationship between Neuroticism and e-banking adoption.

2. There is a positive and meaningful relationship between Extraversion and e-banking adoption.

3. There is a positive and meaningful relationship between Openness to experience and ebanking adoption.

4. There is a negative and meaningful relationship between Agreeableness and e-banking adoption.

5. There is a positive and meaningful relationship between Conscientiousness and e-banking adoption.

The proposed study uses Pearson correlation as well as step-wise regression techniques to examine different hypotheses of this survey. Cronbach alphas for two questionnaires of personal characteristics and e-banking were calculated as 0.79 and 0.73 , respectively.

\subsection{Personal characteristics of the participants}

Fig. 2 demonstrates details of personal characteristics of the participants in our survey.

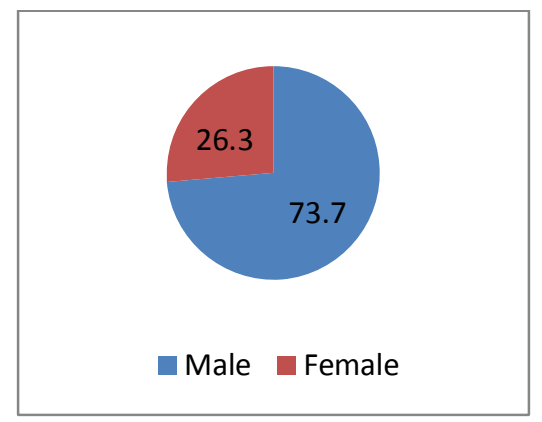

Gender

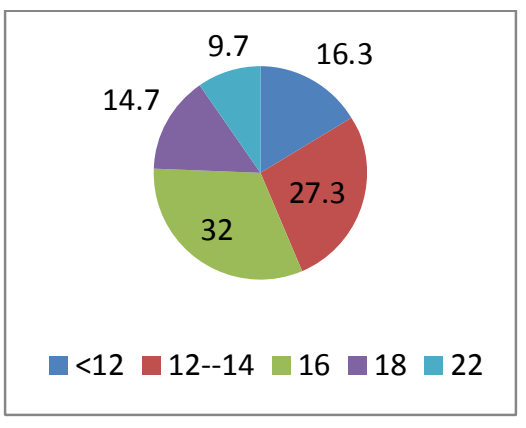

Years of educations

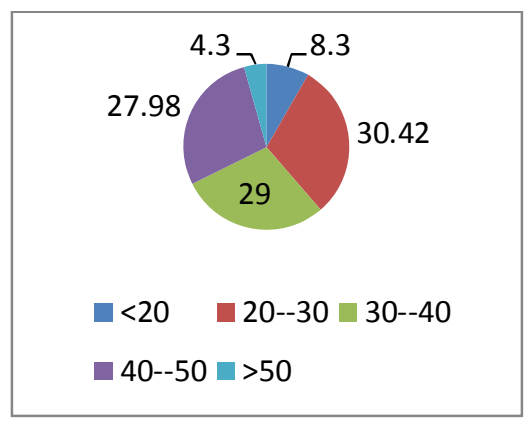

Age

Fig. 2. Frequency of participants

As we can observe from the results of Fig. 2, 73.7\% of the participants were male and only $26.3 \%$ of them were female. In our survey, most participants had some university educations and finally, most of them were young or middle age.

\section{The results}

In this section, we present details of our findings on testing various hypotheses of the survey. Table 1 demonstrates the summary of Pearson correlation on each five components of the survey.

\section{Table 1}

The summary of Pearson correlation ratios

\begin{tabular}{lcccc}
\hline Hypothesis & Pearson cor. & Sig. & $\alpha$ & Result \\
\hline The negative effect of neuroticism on e-banking adoption & -.199 & .001 & .01 & $\sqrt{ }$ \\
The positive effect of extraversion on e-banking adoption & -.187 & .001 & .01 & $\sqrt{ }$ \\
The positive effect of openness to experience on e-banking adoption & -.79 & .170 & .01 & $\times$ \\
The negative effect of agreeableness on e-banking adoption & -.139 & .018 & .05 & $\sqrt{ }$ \\
\hline The positive effect of conscientiousness on e-banking adoption & .160 & .006 & .01 & $\sqrt{ }$ \\
\hline
\end{tabular}


According to Table 1, there is a negative and meaningful relationship between neuroticism and ebanking adoption $(\mathrm{r}=-0.199$, P-value $=0.01)$, a negative relationship between agreeableness and ebanking adoption $(\mathrm{r}=-0.139, \mathrm{P}$-value $=0.01)$ and a positive relationship between conscientiousness and e-banking adoption $(\mathrm{r}=0.160, \mathrm{P}$-value $=0.01)$. These preliminary results help us apply stepwise regression technique summarized in Table 2.

Table 2

The summary of stepwise regression technique

\begin{tabular}{lccccc}
\hline & Coefficient & Non-standard error & Standard error & t-student & Sig. \\
\hline Intercept & 77.757 & 3.386 & & 22.964 & .000 \\
Neuroticism & -.506 & .161 & -.189 & -3.135 & .002 \\
Conscientiousness & .558 & .138 & .246 & 4.028 & .000 \\
Agreeableness & -.321 & .132 & -.152 & -2.431 & .016 \\
\hline
\end{tabular}

The results of regression analysis are consistent with what we expected from three hypotheses. The results also confirm the results of Pearson correlation found earlier in this survey. All three t-student values are significance. Therefore, we can confirm that Neuroticism and Agreeableness have negative impact on online banking adoption while Conscientiousness has positive impact on online banking adoption.

\section{Conclusion}

During the past few years, online banking has become a popular technique among many people in the world. Most banks use new features on their online banking to attract more customers and to have better customer retention. In this paper, we have presented an empirical investigation to examine the effects of five personal characteristics on doing online banking. Using Pearson correlation as well as stepwise regression technique, the study detected that Neuroticism and Agreeableness had negative impact on online banking adoption while Conscientiousness had positive impact on online banking adoption.

\section{Acknowledgement}

The authors would like to thank the anonymous referees for constructive comments on earlier version of this paper.

\section{References}

Agarwal, R., Rastogi, S., \& Mehrotra, A. (2009). Customers' perspectives regarding e-banking in an emerging economy. Journal of Retailing and Consumer Services, 16(5), 340-351.

Akturan, U., \& Tezcan, N. (2012). Mobile banking adoption of the youth market: Perceptions and intentions. Marketing Intelligence \& Planning, 30(4), 444-459.

Calisir, F., \& Gumussoy, C. A. (2008). Internet banking versus other banking channels: Young consumers' view. International Journal of Information Management, 28(3), 215-221.

Chau, V. S., \& Ngai, L. W. (2010). The youth market for internet banking services: perceptions, attitude and behaviour. Journal of Services Marketing, 24(1), 42-60.

Cruz, P., Neto, L. B. F., Muñoz-Gallego, P., \& Laukkanen, T. (2010). Mobile banking rollout in emerging markets: evidence from Brazil. International Journal of Bank Marketing, 28(5), 342371.

Dillon, A., \& Morris, M. G. (1996). User acceptance of new information technology: theories and models. Annual Review of Information science and Technology, 31, 3-32.

Eriksson, K., Kerem, K., \& Nilsson, D. (2008). The adoption of commercial innovations in the former Central and Eastern European markets: The case of internet banking in Estonia. International Journal of Bank Marketing, 26(3), 154-169. 
Gupta, B., Dasgupta, S., \& Gupta, A. (2008). Adoption of ICT in a government organization in a developing country: An empirical study. The Journal of Strategic Information Systems, 17(2), 140154.

Hu, P. J., Chau, P. Y., Sheng, O. R. L., \& Tam, K. Y. (1999). Examining the technology acceptance model using physician acceptance of telemedicine technology. Journal of management information systems, 16(2), 91-112.

Im, I., Kim, Y., \& Han, H. J. (2008). The effects of perceived risk and technology type on users' acceptance of technologies. Information \& Management, 45(1), 1-9.

Jarvenpaa, S. L., \& Todd, P. A. (1996). Consumer reactions to electronic shopping on the World Wide Web. International Journal of Electronic Commerce, 1(2), 59-88.

King, W. R., \& He, J. (2006). A meta-analysis of the technology acceptance model. Information \& Management, 43(6), 740-755.

Koenig-Lewis, N., Palmer, A., \& Moll, A. (2010). Predicting young consumers' take up of mobile banking services. International Journal of Bank Marketing, 28(5), 410-432.

Kuo, Y. F., \& Yen, S. N. (2009). Towards an understanding of the behavioral intention to use 3G mobile value-added services. Computers in Human Behavior, 25(1), 103-110.

Laforet, S., \& Li, X. (2005). Consumers' attitudes towards online and mobile banking in China. International Journal of Bank Marketing, 23(5), 362-380.

Littler, D., \& Melanthiou, D. (2006). Consumer perceptions of risk and uncertainty and the implications for behaviour towards innovative retail services: the case of internet banking. Journal of Retailing and Consumer Services, 13(6), 431-443.

Lu, J., Liu, C., Yu, C. S., \& Wang, K. (2008). Determinants of accepting wireless mobile data services in China. Information \& Management, 45(1), 52-64.

Moon, J. W., \& Kim, Y. G. (2001). Extending the TAM for a World-Wide-Web context. Information \& Management, 38(4), 217-230.

Morris, M. G., \& Dillon, A. (1997). How user perceptions influence software use. Software, IEEE, 14(4), 58-65.

Riquelme, H. E., \& Rios, R. E. (2010). The moderating effect of gender in the adoption of mobile banking. International Journal of Bank Marketing, 28(5), 328-341.

Suoranta, M., \& Mattila, M. (2004). Mobile banking and consumer behaviour: new insights into the diffusion pattern. Journal of Financial Services Marketing,8(4), 354-366.

Venkatesh, V., \& Davis, F. D. (2000). A theoretical extension of the technology acceptance model: four longitudinal field studies. Management science, 46(2), 186-204.

Venkatesh, V., Morris, M. G., Davis, G. B., \& Davis, F. D. (2003). User acceptance of information technology: Toward a unified view. MIS quarterly, 425-478.

Yiu, C. S., Grant, K., \& Edgar, D. (2007). Factors affecting the adoption of Internet Banking in Hong Kong-implications for the banking sector. International Journal of Information Management, 27(5), 336-351. 